\title{
ADAPTABILITAS, PERTUMBUHAN DAN REGENERASI PADA PLOT KONSERVASI EX SITU MERBAU
}

\author{
Adaptability, Growth and Regeneration in Ex Situ Conservation Plots of Merbau
}

Tri Pamungkas Yudohartono dan Burhan Ismail

\author{
Balai Besar Penelitian Bioteknologi dan Pemuliaan Tanaman Hutan Yogyakarta \\ J1. Palagan Tentara Pelajar Km 15, Purwobinangun, Pakem, Sleman Yogyakarta 55583 \\ e-mail : tyudohartono@yahoo.com.sg
}

\begin{abstract}
Merbau is one of threatened forest genetic resources. Based on IUCN Red List Categories. conservation status of merbau is vulnerable (VU Alcd). Conservation effort of merbau is urgently required to save this species from extinction. Center for Forest Biotechnology and Tree Improvement Yogyakarta had established ex situ conservation plots of merbau in Forest Research in Bondowoso, East Java and Gunung Kidul Yogyakarta. Genetic resources used in those ex situ conservation plots were from seven provenances namely Halmahera Timur, Waigo, Oransbari, Wasior, Nabire, Seram, dan Mandopi/Twanwawi. This research aims to evaluate adaptability, growth and regeneration of merbau plants grown in ex situ conservation plots in Bondowoso dan Gunung Kidul. The ex situ conservation plot in Bondowoso was designed as Randomized Complete Block Design with single factor of provenance. At the ex situ conservation plot in Gunung Kidul each provenance was planted in one block. The results showed that adaptability of merbau plants at ex situ conservation plots in Bondowoso dan Gunung Kidul was good. Growth of height and diameter of merbau plants from several provenances at ex situ conservation plot in Gunung Kidul were better than those in Bondowoso at all observation ages. Height and diameter average of merbau plants at ex situ conservation plots in Bondowoso and Gunung Kidul at one year old were $78.21 \mathrm{~cm} ; 9.58 \mathrm{~mm}$ and $97.88 \mathrm{~cm} ; 9.58 \mathrm{~mm}$ respectively. Height and diameter average of merbau plants at ex situ conservation plots in Bondowoso and Gunung Kidul at two years old were $95.36 \mathrm{~cm} ; 12.95 \mathrm{~mm}$ and $121.14 \mathrm{~cm} ; 19.62 \mathrm{~mm}$ respectively. Regeneration of merbau has been successful at Gunung Kidul plot. Some of the fallen seeds were then grown to be wildlings. Whereas, regeneration of merbau at ex situ conservation plot in Bondowoso was regarded as not successful.
\end{abstract}

Kata-kata kunci : merbau, conservation, adaptability, growth, regeneration

\begin{abstract}
ABSTRAK
Salah satu sumber daya genetik tanaman hutan yang saat ini terancam adalah merbau. Berdasarkan kategori IUCN Red List status konservasi merbau sudah termasuk kategori rawan (VU A1cd). Upaya konservasi sumberdaya genetik jenis merbau mutlak diperlukan untuk menyelamatkan jenis ini dari kepunahan. Balai Besar Penelitian Bioteknologi dan Pemuliaan Tanaman Hutan Yogyakarta telah melakukan pembangunan plot konservasi ex situ merbau di Hutan Penelitian Sumberwringin, Bondowoso, Jawa Timur dan Hutan Penelitian Petak 93 G unung Kidul. Materi genetik yang digunakan untuk pembangunan plot konservasi ex situ merbau tersebut berasal dari 7 provenan yaitu provenan Halmahera Timur, Waigo, Oransbari, Wasior, Nabire, Seram, dan Mandopi/Twanwawi. Penelitian ini bertujuan untuk mengetahui kemampuan hidup/adaptabilitas, pertumbuhan dan regenerasi merbau pada plot konservasi ex situ merbau di Bondowoso dan Gunung Kidul. Hasil penelitian menunjukkan bahwa kemampuan hidup atau adaptabilitas tanaman merbau pada plot konservasi ex situ di Petak 93, Gunung Kidul dan HP Sumberwringin, Bondowoso tergolong baik. Pertumbuhan tinggi dan diameter tanaman merbau dari berbagai provenan pada plot konservasi ex situ Gunung Kidul lebih baik dibandingkan Bondowoso pada semua umur pengamatan. Regenerasi merbau sudah berhasil pada plot konservasi ex situ di Gunung Kidul. Semua tahapan pembungaan merbau pada plot konservasi ex situ di Gunung Kidul telah berhasil. Selanjutnya, biji merbau yang jatuh sudah mampu berkembang menjadi anakan alam. Sementara itu, pa da plot konservasi ex situ di Bondowoso regenerasi merbau belum berhasil.
\end{abstract}

Kata-kata kunci : merbau, konservasi, adaptasi, pertumbuhan, regenerasi

Tanggal diterima : 10 September 2013 ; Direvisi : 17 Oktober 2013; Disetujui terbit :18 November 2013 


\section{PENDAHULUAN}

Merbau merupakan satu dari sekian banyak sumber daya genetik tanaman hutan yang terancam eksisitensinya pada habitat alamnya. Berdasarkan kategori IUCN Red List status konservasi merbau sudah termasuk kategori rawan (VU A1cd) yang artinya telah terjadi penurunan populasi merbau lebih dari $20 \%$ selama lebih dari 10 tahun terakhir yang disebabkan oleh penurunan wilayah penyebaran, wilayah keberadaan dan/atau penurunan kualitas habitat dan tingkat eksploitasi potensial dan aktual. Upaya konservasi sumberdaya genetik jenis merbau mutlak diperlukan untuk menyelamatkan merbau dari ancaman kepunahan. Beberapa hal yang melandasi pentingnya upaya konservasi sumberdaya genetik adalah untuk mempertahankan keberadaan individu pohon dan populasinya serta memeberikan peluang pemanfaatan dari sumberdaya genetik. Berdasarkan pertimbangan tersebut maka perlu diketahui informasi mengenai kemampuan hidup/adaptabilitas, regenerasi dan karakteristik/sifat yang penting dari sumberdaya genetik yang dikonservasi. Regenerasi sumberdaya genetik merupakan bagian yang penting dari strategi konservasi karena berhasilnya suatu program konservasi hanya dapat dinilai setelah sumberdaya tersebut beregenerasi (Finkelday, 2005). Balai Besar Penelitian
Bioteknologi dan Pemuliaan Tanaman Hutan Yogyakarta telah melakukan upaya konservasi sumberdaya genetik melalui pembangunan plot konservasi ex situ merbau. Plot konservasi ex situ merbau tersebut dibangun di Hutan Penelitian Sumberwringin, Bondowoso, Jawa Timur dan Hutan Penelitian Petak $93 \mathrm{G}$ unung Kidul pada tahun 2006. Materi genetik yang digunakan dalam pembangunan kedua plot konservasi tersebut berasal dari provenan yang sama yaitu Halmahera Timur, Waigo, Nabire, Seram, Wasior, Oransbari, dan Mandopi/Twanwawi. Sampai saat ini data dan informasi mengenai adaptabilitas, pertumbuhan dan regenerasi merbau masih kurang atau belum tersedia.

Kemampuan suatu jenis tanaman untuk beradaptasi, tumbuh dan berkembang dipengaruhi oleh faktor eksternal seperti tanah, iklim dan ketinggian tempat dan faktor internal (genetik). Plot konservasi ex situ merbau di Bondowoso dan Gunung Kidul memiliki karakteristik tempat tumbuh (tipe iklim, jenis tanah dan elevasi) yang berbeda. Perbedaan karakteristik tempat tumbuh pada kedua plot konservasi ex situ merbau tersebut akan memberikan pengaruh yang berbeda terhadap kemampuan tanaman merbau untuk beradaptasi, tumbuh dan berkembang. Sedangkan dari faktor internal, tingginya keragaman genetik merbau dari dari 
keenam populasi merbau (Halmahera Timur, Waigo, Oransbari, Wasior, Nabire, dan Seram) akan memberikan pengaruh positif terhadap kemampuan merbau untuk beradaptasi pada lingkungan yang baru (di luar habitat alaminya). Jenis tanaman yang mempunyai keragaman genetik tinggi akan mempunyai peluang yang semakin besar untuk tumbuh dan berkembang dalam suatu lingkungan tumbuh yang ada. Tingkat keragaman genetik mencerminkan perlunya suatu sumberdaya genetik untuk dapat beradaptasi ekologi dalam jangka pendek dan beradaptasi dengan perubahan evolusi jangka panjang. Suatu spesies harus mempunyai keragaman genetik yang memadai supaya dapat bertahan hidup menghadapi tekanan lingkungan yang melampaui ambang batas plastisitas perkembangan (Lande dan Shannon, 1996 dalam Lee, S.L., dkk, 2002). Bertitik tolak dari hal tersebut maka penelitian ini dilakukan dengan tujuan untuk mengetahui pengaruh tempat tumbuh dan faktor genetik terhadap adaptabilitas, pertumbuhan dan regenerasi tanaman merbau pada plot konservasi ex situ merbau di Bondowoso, dan (2) mengetahui pengaruh tempat tumbuh dan faktor genetik terhadap adaptabilitas, pertumbuhan dan regenerasi tanaman merbau pada plot konservasi ex situ merbau di Gunung Kidul.

\section{BAHAN DAN METODE}

\section{A. Lokasi Penelitian}

Kegiatan penelitian dilakukan pada plot konservasi ex situ merbau di Hutan Penelitian Sumberwringin, Bondowoso, Jawa Timur dan Hutan Penelitian Petak 93 Gunung Kidul. Hutan Penelitian (HP) Sumberwringin Bondowoso secara administratif terletak di Desa Wringinanom, Kecamatan Sukosari, Kabupaten Bondowoso (Mahfudz, et al, 2006). Menurut klasifikasi iklim Schmidt dan Ferguson, Hutan Penelitian Sumberwringin termasuk iklim B dengan curah hujan 2400 $\mathrm{mm} /$ tahun. Hari hujan terbanyak pada bulan Januari dan menurun mulai bulan Juni. Jenis tanahnya adalah asosiasi andosol coklat, kelerengan berkisar antara $0-15$ $\%$ dan merupakan fisiografi dataran dengan ketinggian $\pm 800 \mathrm{~m}$ di atas permukaan laut. Tumbuhan penutup tanah yang banyak dijumpai di dalam plot penelitian adalah semak dan alang-alang. Hutan Penelitian Petak 93 Gunung Kidul secara administratif terletak di Desa Banyusuto, Kecamatan Playen, Kabupaten Gunung Kidul, Propinsi Daerah Istimewa Yogyakarta. Menurut klasifikasi iklim Schmidt dan Ferguson, Hutan Penelitian Petak 93 memiliki iklim C dengan curah hujan $1.894 \mathrm{~mm} /$ tahun. Musim hujan dimulai bulan November dan mulai berkurang pada bulan Maret. Topografi wilayah HP petak 93 
bergelombang sampai agak curam dengan kelerengan $8-30 \%$. Kondisi tanah sebagian berbatu, jenis tanah vertisol, bahan induk napal dan tufvolkan dengan tingkat kesburan rendah hingga sedang. Ketinggian tempat kurang lebih $150 \mathrm{~m}$ dpl. Tumbuhan penutup tanah yang banyak dijumpai di dalam plot penelitian adalah semak dan alang-alang (PPPBPTH, 2004).

\section{B. Bahan Penelitian}

Bahan yang digunakan dalam penelitian ini adalah tanaman merbau pada plot konservasi ex situ merbau di Hutan Penelitian Sumberwringin, Bondowoso dan Hutan Penelitian Petak 93 Gunung Kidul. Provenan yang digunakan dalam kedua plot tersebut sama. Provenan tersebut adalah Halmahera Timur, Waigo, Oransbari, Wasior, Nabire, Seram, dan Mandopi/Twanwawi. Deskripsi dari setiap provenan disajikan pada Tabel 1.

Tabel 1. Provenan merbau yang digunakan dalam penelitian

\begin{tabular}{|l|l|l|l|c|l|}
\hline No & \multicolumn{1}{|c|}{ Provenan } & \multicolumn{1}{|c|}{ Jenis tanah } & $\begin{array}{l}\text { Lereng } \\
(\%)\end{array}$ & \multicolumn{1}{|c|}{$\begin{array}{c}\text { Elevasi } \\
(\mathrm{m} \mathrm{dpl})\end{array}$} & \multicolumn{1}{|c|}{ Koordinat } \\
\hline 1. & Halmahera Timur & $\begin{array}{l}\text { Podsolik merah kuning } \\
\text { hidromorf kelabu }\end{array}$ & $0-15$ & $50-400$ & $\begin{array}{l}0^{\circ} 48^{\prime} \mathrm{LU} \\
127^{\circ} 52^{\prime} \mathrm{BT}\end{array}$ \\
\hline 2. & Waigo & $\begin{array}{l}\text { Podsolik merah kuning } \\
\text { hidromorf kelabu }\end{array}$ & $<3$ & $50-200$ & $\begin{array}{l}1^{\circ} 23^{\prime} \mathrm{LS} \\
131^{\circ} 58^{\prime} \mathrm{BT}\end{array}$ \\
\hline 3. & Nabire & $\begin{array}{l}\text { Podsolik merah kuning } \\
\text { hidromorf kelabu }\end{array}$ & $<3$ & $0-100$ & $\begin{array}{l}3^{\circ} 38^{\prime} \mathrm{LS} \\
135^{\circ} 13^{\prime} \mathrm{BT}\end{array}$ \\
\hline 4. & Seram & $\begin{array}{l}\text { Latosol, renzina, } \\
\text { mediteran }\end{array}$ & $<3$ & $200-500$ & $\begin{array}{l}2^{\circ} 55^{\prime} \mathrm{LS} \\
128^{\circ} 48^{\prime} \mathrm{BT}\end{array}$ \\
\hline 5. & Wasior & $\begin{array}{l}\text { Podsolik merah kuning } \\
\text { hidromorf kelabu }\end{array}$ & $<3$ & $200-500$ & $\begin{array}{l}2^{\circ} 31^{\prime} \mathrm{LS} \\
134^{\circ} 32^{\prime} \mathrm{BT}\end{array}$ \\
\hline 6. & Oransbari & $\begin{array}{l}\text { Podsolik merah kuning } \\
\text { hidromorf kelabu }\end{array}$ & $<3$ & $50-200$ & $\begin{array}{l}1^{\circ} 19^{\prime} \mathrm{LS} \\
134^{\circ} 15^{\prime} \mathrm{BT}\end{array}$ \\
\hline 7. & $\begin{array}{l}\text { Mandopi/ } \\
\text { Twanwawi }\end{array}$ & $\begin{array}{l}\text { Podsolik coklat kelabu } \\
\text { Podsolik merah kuning } \\
\text { hidromorf kelabu }\end{array}$ & $<3$ & $0-400$ & $\begin{array}{l}4^{\circ} 03^{\prime} \mathrm{LS} \\
135^{\circ} 12^{\prime} \mathrm{BT}\end{array}$ \\
\hline
\end{tabular}

Plot konservasi ex situ merbau di Hutan Penelitian Sumberwringin, Bondowoso, Jawa Timur dibangun pada tahun 2006 dan didesain sebagi uji provenan. Desain penelitian yang digunakan dalam plot uji provenan merbau tersebut adalah Rancangan Acak Lengkap Berblok
(Randomized Complete Block Design) dengan $\mathrm{s}$ atu faktor perlakuan yaitu provenan. Setiap provenan t erdiri dari 4 blok yang sekaligus berfungsi sebagai ulangan. Setiap provenan dalam setiap blok terdiri dari 60 tanaman. Plot berbentuk persegi panjang dengan ukuran $5 \mathrm{x} \quad 15$. 
Jarak tanam yang digunakan pada plot uji provenan adalah $3 \times 3 \mathrm{~m}$. Plot konservasi $e x$ situ merbau di Hutan Penelitian Petak 93 Gunung Kidul dibangun pada tahun 2007. Pada plot konservasi ex situ merbau di Hutan Penelitian Petak 93 Gunung Kidul setiap provenan ditanam dalam satu blok tersendiri dan terpisah dari provenan lainnya. Setiap provenan terdiri dari 64 tanaman. Jarak tanam yang digunakan adalah 5 x 5 m (Mahfudz, et al, 2006).

\section{Karakteristik yang diukur}

Pengamatan karakteristik dilakukan pada seluruh tanaman pada plot konservasi ex situ merbau di HP Sumberwringin, Bondowoso dan Petak 93, Gunung Kidul. Karakteristik yang diamati adalah persen hidup, tinggi, diameter, pembungaan dan regenerasi alam. Menurut Ginwal dan Mandal (2004), persen hidup tanaman mengindikasikan adaptabilitas/kemampuan beradaptasi suatu provenan terhadap kondisi lingkungan pada lokasi uji (trial site). Pengamatan persen hidup dilakukan sebelum dilakukan penyulaman tanaman pada plot konservasi. Pengukuran tinggi dan diameter dilakukan sampai dengan umur $2 \mathrm{t}$ ahun. Hal ini dikarenakan pada tahun ke-3 sebagian besar tanaman pada plot konservasi ex situ merbau di Petak 93, Gunung Kidul mengalami kebakaran. Tinggi pohon diukur dari permukaan tanah sampai titik tumbuh apikal (ujung tanaman). Diameter batang diukur pada ketinggian $10 \mathrm{~cm}$ di atas permukaan tanah. Pengukuran tinggi dan diameter dilakukan terhadap seluruh tanaman dalam plot konservasi. Pengamatan pembungaan dan regenerasi dilakukan secara deskriptif dengan melihat tahap pembungaan yang ada, ada tidaknya anakan merbau dan tidak dilakukan pengumpulan data kuantitatif mengenai jumlah tanaman yang berbunga maupun tidak dilakukan penghitungan jumlah anakan di dalam plot konservasi . Berdasarkan pengamatan pada kedua plot konservasi, merbau mulai berbunga pada umur $4 \mathrm{t}$ ahun dan anakan alam dijumpai pada umur 6 tahun.

\section{Analisis Data}

Data hasil pengukuran tinggi dan diamter dianalisis dengan menggunakan analisis varian untuk mengetahui variasi antar provenan. Analisis varian hanya dilakukan untuk hasil pengukuran tinggi dan diameter tanaman pada plot konservasi ex situ merbau di Bondowoso pada umur 1 dan 2 tahun. Analisis varian tidak dilakukan pada plot konservasi ex situ merbau di Petak 93, G unung Kidul. Pada plot konservasi ex situ merbau di Petak 93 Gunung Kidul setiap provenan ditanam dalam satu blok tersendiri dan kondisi penutupan lahan antar blok tidak sama. Model matematis yang digunakan adalah: 


$$
Y_{i j}=\mu+B_{i}+P_{j}+\varepsilon_{i j}
$$

$$
\begin{array}{ll}
\operatorname{dimana}: \quad \mathrm{Y}_{\mathrm{ij}} \quad \text { Karakteristik yang } \\
& \text { diamati/diukur } \\
\mu & =\text { Rerata umum } \\
\mathrm{P}_{\mathrm{j}} & =\text { Pengaruh provenan ke- } \\
\mathrm{j} & \\
\mathrm{B}_{\mathrm{i}} & =\text { Efek blok ke- } \mathrm{i} \\
\varepsilon_{\mathrm{ij}} & =\text { Random error pada } \\
& \text { pengamatan ke-ij }
\end{array}
$$

\section{HASIL DAN PEMBAHASAN}

\section{A. Persen hidup}

Hasil pengamatan persen hidup tanaman merbau pada pada plot konservasi ex situ di HP Sumberwringin, Bondowoso dan Petak 93, Gunung Kidul pada umur 6 dan 12 bulan disajikan pada Tabel 2 .

Tabel 2. Persen hidup tanaman merbau pada plot konservasi ex situ di HP Sumberwringin, Bondowoso dan Petak 93, Gunung Kidul pada umur 6 dan 12 bulan

\begin{tabular}{|r|l|c|c|c|c|}
\hline \multirow{2}{*}{ No } & \multirow{2}{*}{ Populasi } & \multicolumn{2}{|c|}{ Umur 6 bulan (\%) } & \multicolumn{2}{c|}{ Umur 12 bulan (\%) } \\
\cline { 3 - 6 } & & Bondowoso & Gunung Kidul & Bondowoso & Gunung Kidul \\
\hline 1 & Halmahera Timur & 100 & 98,44 & 98,33 & 84,38 \\
\hline 2 & Waigo & 99 & 100,00 & 96,11 & 92,19 \\
\hline 3 & Nabire & 99 & 96,88 & 98,33 & 28,13 \\
\hline 4 & Seram & 100 & 100,00 & 97,72 & 70,31 \\
\hline 5 & Oransbari & 100 & 96,88 & 97,22 & 18,75 \\
\hline 6 & Wasior & 100 & 100,00 & 100,00 & 75,00 \\
\hline 7 & Mandopi/Twanwawi & 99 & 90,63 & 90,98 & 73,44 \\
\hline
\end{tabular}

Rata-rata persen hidup dari masingmasing provenan merbau pada plot konservasi ex situ Petak 93, Gunung Kidul pada umur 6 bulan, di HP Sumberwringin, Bondowoso pada umur 6 bulan dan 1 tahun tergolong tinggi yaitu diatas $90 \%$. Ratarata persen hidup dari masing-masing provenan merbau pada plot konservasi ex situ Petak 93, Gunung Kidul pada umur 12 bulan mengalami penurunan yang lebih besar dibandingkan plot konservasi ex situ Petak 93, Gunung Kidul pada umur 6 bulan, di HP Sumberwringin, Bondowoso terutama provenan Nabire dan Oransbari. Penurunan rata-rata persen hidup provenan Nabire dan Oransbari hingga di bawah $30 \%$ tersebut disebabkan karena terjadinya kebakaran.

Meskipun terjadi penurunan persen hidup tetapi tanaman merbau dapat beradaptasi dengan cukup baik pada kedua plot konservasi tersebut. Hal ini disebabkan karena kondisi lingkungan di plot konservasi ex situ merbau tersebut memenuhi kriteria persyaratan tumbuh merbau dan tingginya keragaman genetik 
merbau. Pada sebaran alaminya merbau dijumpai tumbuh hingga ketinggian $1000 \mathrm{~m}$ dpl pada berbagai jenis tanah kecuali tanah gambut dengan tipe iklim A-D (Mahfudz et al., 2006). Hutan Penelitian Sumberwringin yang terletak pada ketinggian $\pm 800 \mathrm{~m}$ di atas permukaan laut mempunyai tipe iklim B dan jenis tanah asosiasi andosol coklat. Hutan Penelitian Petak 93 yang terletak pada ketinggian $\pm 150 \mathrm{~m}$ dpl memiliki iklim $\mathrm{C}$ dan jenis tanah vertisol dengan kondisi tanah sebagian berbatu. Hasil penelitian Yudohartono (2008) menunjukkan bahwa rata-rata nilai keragaman genetik merbau dari keenam populasi merbau (Halmahera Timur, Waigo, Oransbari, Wasior, Nabire, dan Seram) tergolong tinggi yaitu 0,392 . Ratarata keragaman genetik $I$. bijuga ini lebih tinggi dibandingkan keragaman genetik
I. palembanica yakni sebesar 0,242 ( Lee, et al., 2002), semua jenis tanaman $(0,113)$, tanaman tropis $(0,211)$ dan tanaman kayu berumur panjang (0,149; Hamrick, et al., 1991). Keragaman genetik merupakan komponen yang sangat menentukan kemampuan suatu jenis untuk dapat beradaptasi terhadap perubahan lingkungan dalam jangka panjang. Jenis tanaman yang mempunyai keragaman genetik tinggi akan mempunyai peluang yang semakin besar untuk tumbuh dan berkembang dalam suatu lingkungan tumbuh yang ada.

\section{B. Pertumbuhan tinggi dan diameter}

Hasil pengamatan karakteristik pertumbuhan tanaman merbau pada pada plot konservasi ex situ di HP Sumberwringin, Bondowoso dan Petak 93, Gunung Kidul pada umur 6 dan 12 bulan disajikan pada Tabel 3 dan 4 .

Tabel 3. Tinggi tanaman merbau pada plot konservasi ex situ di HP Sumberwringin, Bondowoso dan Petak 93, Gunung Kidul pada umur 12 dan 24 bulan

\begin{tabular}{|r|l|c|c|c|c|}
\hline \multirow{2}{*}{ No } & \multirow{2}{*}{ Populasi } & \multicolumn{2}{|c|}{ Umur 12 bulan $(\mathrm{cm})$} & \multicolumn{2}{c|}{ Umur 24 bulan $(\mathrm{cm})$} \\
\cline { 3 - 6 } & & Bondowoso & Gunung Kidul & Bondowoso & Gunung Kidul \\
\hline 1 & Halmahera Timur & 75,72 & 95,22 & 96,41 & 106,77 \\
\hline 2 & Waigo & 87,77 & 99,68 & 102,89 & 105,15 \\
\hline 3 & Nabire & 83,17 & 107,67 & 94,21 & 143,95 \\
\hline 4 & Seram & 48,97 & 80,98 & 59,93 & 101,49 \\
\hline 5 & Oransbari & 80,70 & 105,17 & 96,86 & 140,19 \\
\hline 6 & Wasior & 91,83 & 91,02 & 110,55 & 111,40 \\
\hline 7 & Mandopi/Twanwawi & 79,34 & 105,45 & 106,68 & 139,00 \\
\hline
\end{tabular}


Tabel 4. Diameter tanaman merbau pada plot konservasi ex situ di HP Sumberwringin, Bondowoso dan Petak 93, Gunung Kidul pada umur 12 dan 24 bulan

\begin{tabular}{|r|l|c|c|c|c|}
\hline \multirow{2}{*}{ No } & \multirow{2}{*}{ Populasi } & \multicolumn{2}{|c|}{ Umur 12 bulan $(\mathrm{mm})$} & \multicolumn{2}{c|}{ Umur 24 bulan (mm) } \\
\cline { 3 - 6 } & & Bondowoso & Gunung Kidul & Bondowoso & Gunung Kidul \\
\hline 1 & Halmahera Timur & 10,26 & 11,31 & 14,61 & 13,50 \\
\hline 2 & Waigo & 9,68 & 1,84 & 13,64 & 12,58 \\
\hline 3 & Nabire & 9,49 & 10,93 & 12,02 & 15,72 \\
\hline 4 & Seram & 7,00 & 9,23 & 9,03 & 32,08 \\
\hline 5 & Oransbari & 9,83 & 11,31 & 13,31 & 14,47 \\
\hline 6 & Wasior & 10,19 & 11,51 & 13,97 & 34,51 \\
\hline 7 & Mandopi/Twanwawi & 10,62 & 10,90 & 14,09 & 14,50 \\
\hline
\end{tabular}

Dari Tabel 3 da n 4 di ketahui bahwa rata-rata nilai karakteristik pertumbuhan tanaman merbau baik tinggi dan diameter untuk setiap provenan pada plot konservasi ex situ Petak 93, Gunung Kidul lebih baik dibandingkan HP Sumberwringin, Bondowoso pada semua umur pengamatan. Hal ini diduga dipengaruhi oleh kondisi tempat tumbuh pada kedua plot tersebut. Plot konservasi ex situ di Bondowoso terletak pada ketinggian terletak pa da ketinggian $\pm 800 \mathrm{~m}$ di atas permukaan laut dengan tipe iklim B dan plot konservasi ex situ di Gunung Kidul terletak pada ketinggian \pm $150 \mathrm{~m}$ dpl dengan tipe iklim C. Iklim akan berubah dengan perbedaan ketinggian tempat. Ketinggian tempat mempunyai efek tidak langsung terhadap riap dan bentuk pohon hutan. Pertumbuhan tinggi tanaman dan riap tanaman akan menurun seiring dengan bertambahnya ketinggian tempat (Soetrisno, 1998).

Berdasarkan data pada kedua tabel di atas juga terlihat adanya variasi karakter pertumbuhan tinggi dan diameter antar provenan merbau yang diuji. Untuk mengetahui variasi antar provenan untuk sifat tinggi dan diameter maka dilakukan analisis varian terhadap data pengukuran tinggi dan diameter. Analisis varian tidak dilakukan pada plot konservasi ex situ merbau di Petak 93, Gunung Kidul. Pada plot konservasi ex situ merbau di Petak 93 Gunung Kidul setiap provenan ditanam dalam satu blok tersendiri dan kondisi penutupan lahan antar blok tidak sama. Hasil analisis varian untuk sifat tinggi dan diameter pada plot konservasi ex situ merbaudi Bondowoso pada umur 1, $\mathrm{d}$ an 2 tahun disajikan pada Tabel 5 dan 6 . 
Tabel 5. Analisis varian untuk sifat tinggi tanaman pada plot konservasi ex situ merbaudi Bondowoso pada umur 1, dan 2 tahun

\begin{tabular}{|l|c|c|c|c|c|}
\hline \multicolumn{7}{|c|}{ Umur 1 Tahun } \\
\hline $\begin{array}{c}\text { Sumber } \\
\text { Variasi }\end{array}$ & $\begin{array}{c}\text { Derajad } \\
\text { Bebas }\end{array}$ & $\begin{array}{c}\text { Jumlah } \\
\text { Kuadrat }\end{array}$ & $\begin{array}{c}\text { Kuadrat } \\
\text { Tengah }\end{array}$ & F & Sig. \\
\hline Provenan & 5 & 3506,23 & 701,25 & $101,29^{* *}$ & 0,000 \\
\hline Blok & 2 & 207,00 & 103,50 & $14,95^{* *}$ & 0,001 \\
\hline Error & 10 & 69,23 & 6,92 & & \\
\hline \multicolumn{7}{|c|}{ Umur 2 Tahun } \\
\hline Sumber & Derajad & Jumlah & Kuadrat & F & Sig. \\
\hline Variasi & Bebas & Kuadrat & Tengah & & \\
\hline Provenan & 5 & 4576,67 & 915,33 & $27,00^{* *}$ & 0,000 \\
\hline Blok & 2 & 63,94 & 318,47 & $9,40^{* *}$ & 0,005 \\
\hline Error & 10 & 338,97 & 33,89 & & \\
\hline
\end{tabular}

Tabel 6. Analisis varian untuk sifat diameter tanaman pada plot konservasi ex situ merbau di Bondowoso pada umur 1, dan 2 tahun

\begin{tabular}{|l|c|c|c|c|c|}
\hline \multicolumn{7}{|c|}{ Umur 1 Tahun } \\
\hline $\begin{array}{c}\text { Sumber } \\
\text { Variasi }\end{array}$ & $\begin{array}{c}\text { Derajad } \\
\text { Bebas }\end{array}$ & $\begin{array}{c}\text { Jumlah } \\
\text { Kuadrat }\end{array}$ & $\begin{array}{c}\text { Kuadrat } \\
\text { Tengah }\end{array}$ & F & Sig. \\
\hline Provenan & 5 & 22,08 & 4,42 & $17,47^{* *}$ & 0,000 \\
\hline Blok & 2 & 1,21 & 0,60 & $2,38 \mathrm{~ns}$ & 0,142 \\
\hline Error & 10 & 2,53 & 0,25 & & \\
\hline \multicolumn{7}{|c|}{ Umur 2 Tahun } \\
\hline Sumber & Derajad & Jumlah & Kuadrat & F & Sig. \\
\hline \multicolumn{1}{|c|}{ Variasi } & Bebas & Kuadrat & Tengah & & 0,002 \\
\hline Provenan & 5 & 55,32 & 11,06 & $8,38^{* *}$ & 0,590 \\
\hline Blok & 2 & 1,48 & 0,74 & $0,56^{\text {ns }}$ & 0,5 \\
\hline Error & 10 & 13,20 & 1,32 & & \\
\hline
\end{tabular}

Keterangan $* *$ = berbeda nyata pada taraf uji $1 \%$ ns $=$ tidak berbeda nyata

Dari Tabel 3 diketahui bahwa tanaman merbau pada kedua plot konservasi ex situ yang memiliki rata-rata tinggi terendah dan tertinggi pada umur 12 dan 24 bulan berasal dari provenan yang sama. Pada plot konservasi ex situ di HP Sumberwringin, Bondowoso, rata-rata tinggi terendah berasal dari provenan Seram dan tertinggi dari provenan Wasior. Pada plot konservasi ex situ di Petak 93, Gunung Kidul, rata-rata tinggi terendah berasal dari provenan Seram dan tertinggi dari provenan Nabire. Dari Tabel 4 diketahui bahwa tanaman merbau pada kedua plot konservasi ex situ yang memiliki rata-rata diameter terendah pada umur 12 dan 24 bulan berasal dari provenan yang sama yaitu provenan Seram. Sedangkan rata-rata diameter tertinggi berasal provenan yang berbeda. Dari Tabel 5 dan 6 diketahui bahwa terdapat perbedaan 
yang nyata diantara provenan yang diuji untuk sifat tinggi dan diameter tanaman di plot konservasi ex situ merbau di HP Sumberwringin, Bondowoso pada umur 1 dan 2 tahun. Perbedaan tersebut menunjukkan bahwa provenan memberikan pengaruh terhadap karakterisitik tinggi dan diameter tanaman merbau pada umur 1 dan 2 tahun.

Provenan Seram selalu memiliki nilai rata-rata terendah untuk karakteristik tinggi dan diameter pada semua umur pengamatan di kedua plot konservasi ex situ tersebut. Hasil uji Duncan untuk karakteristik tinggi dan diameter keenam provenan merbau (Halmahera Timur, Waigo, Oransbari, Wasior, Nabire, dan Seram) pada umur 1 hingga 3 t ahun pada plot konservasi ex situ di HP Sumberwringin, Bondowoso juga menunjukkan bahwa provenan Seram membentuk kelompok tersendiri dan terpisah dari provenan lain (Yudohartono, 2012). Hal ini juga diperkuat dari hasil analisis isozim terhadap keenam provenan tersebut. Yudohartono (2008) menyatakan bahwa hasil analisis klaster UPGMA berdasarkan Nei's standard genetic distance (1972) menunjukkan bahwa keenam populasi merbau membentuk tiga klaster utama. Populasi Haltim dan Waigo membentuk klaster pertama, populasi Nabire, Oransbari dan Wasior membentuk klaster kedua. Populasi Seram membentuk klaster ketiga yang jauh terpisah dari kedua klaster lainnya. Pola pengelompokan ini diduga dipengaruhi oleh sejarah terbentuknya pulau Seram. Menurut Whitmore (1987), pada awalnya Halmahera, Seram dan Papua merupakan satu daratan dari daratan besar AustraliaNew Guinea yang merupakan bagian dari Australian Gondwanaland. Perbedaan waktu pemisahan Seram dan Halmahera dari daratan besar Australia-New Guinea mengakibatkan perbedaan struktur genetik yang jauh di antara keduanya. Pulau Seram diduga terpisah dari daratan Australia-New Guinea jauh lebih dahulu dibandingkan Halmahera. Pulau Seram yang terlepas jauh terlebih dahulu dan dipisahkan oleh lautan mengalami isolasi reproduksi dan adaptasi lokal terhadap lingkungan setempat yang menyebabkan semakin meningkatnya diferensiasi genetik antara populasi merbau di Seram dan populasi-populasi merbau dari Halmahera dan Papua. Menurut Loveless dan Hamrick (1984), diferensiasi genetik antar populasi dipengaruhi oleh adanya aliran gen melalui penyebaran serbuk sari dan biji. Spesies dengan populasi diskontinyu dan terisolasi menunjukkan kenaikan tingkat diferensiasi genetik karena turunnya aliran gen. Perbedaan struktur genetik tersebut dapat diekspresikan melalui perbedaan karakteristik tanaman. Seram merupakan provenan yang unik karena pada lokus tertentu ada alel yang hanya dimiliki populasi Seram dan tidak 
dimiliki oleh kelima populasi yang lain (Yudohartono, 2008). Menurut Zobel, et.al., (1976) kebanyakan jenis tanaman hutan mempunyai satu sampai beberapa provenan yang memiliki sifat genetik penting yang bersifat unik satu sama lain dan sebaliknya. Oleh karena itu, pekerjaan besar pertama dalam konservasi kompleks gen bagi para pemulia tanaman adalah menyelamatkan sifat yang unik dari suatu provenan. Dengan adanya variasi genetik yang tinggi antar provenan merbau maka semakin besar juga potensi dari sumber daya genetik merbau yang bisa diselamatkan dan dimanfaatkan untuk mendukung program pemuliaan jenis merbau.

\section{Regenerasi}

Regenerasi sumberdaya genetik merupakan bagian yang penting dari strategi konservasi karena berhasilnya suatu program konservasi hanya dapat dinilai setelah sumberdaya tersebut beregenerasi (Finkelday, 2005). Regenerasi diawali dengan kemampuan suatu tanaman untuk melalui semua tahapan dalam pembungaan. Pembungaan pada tanaman hutan yang berumur panjang (perenial) merupakan proses yang sangat kompleks. Hal ini disebabkan adanya interaksi tanaman dengan kondisi lingkungan sepanjang waktu setiap tahun. Proses pembungaan pada dasarnya merupakan interaksi faktor eksternal/lingkungan (cahaya, suhu, kelembaban) dan faktor internal sperti genetik (Thomas, 1993).

Tanaman merbau memiliki biseksual yaitu mempunyai bunga jantan dan betina dalam satu bunga. Bunga merbau mempunyai empat kelopak bunga yang berwarna kehijauan, satu mahkota bunga dan tiga benang sari. Mahkota bunga berwarna putih (dengan bagian tengah berwarna merah) atau merah muda mendekati ungu atau merah. Bunga terletak dibagian aksiler. Polinator utama bunga merbau adalah serangga (lebah), burung dan angin (Thaman, et al., 2006). Hasil pengamatan pada plot konservasi ex situ merbau di Gunung Kidul dan Bondowoso menunjukkan bahwa bunga merbau termasuk bunga heterostili yaitu bunga yang memiliki tangkai putik (stylus) dan tangkai sari (filamen) yang tidak sama panjang. Pada bunga merbau tangkai putik lebih panjang dari tangkai sari (Gambar 1). Tipe bunga heterostili memungkinkan terjadinya penyerbukan terbuka atau kawin silang. Nilai rerata perkawinan silang pada multi lokus $\left(\mathrm{t}_{\mathrm{m}}\right)$ untuk populasi merbau dari Manokwari dan Kerom sama yaitu sebesar 1,000. Nilai rerata perkawinan silang pada suatu lokus $\left(\mathrm{t}_{\mathrm{s}}\right)$ untuk populasi Manokwari dan Kerom masing-masing 0,981 dan 0,972. N ilai $t_{m}$ dan $t_{s}$ yang besar menunjukkan bahwa kemungkinan terjadinya kawin silang luar pada kedua 
populasi tersebut sangat besar. Nilai $t_{m}-t_{s}$ (biparental inbreeding) untuk populasi Manokwari dan Kerom masing-masing sebesar 0,019 da $\mathrm{n} \quad 0,028 . \mathrm{N}$ ilai ini mengindikasikan bahwa kemungkinan terjadinya perkawinan kerabat adalah kecil yaitu 2,8\% untuk populasi Kerom dan 1,9 $\%$ untuk populasi Manokwari. Nilai $r_{p}$

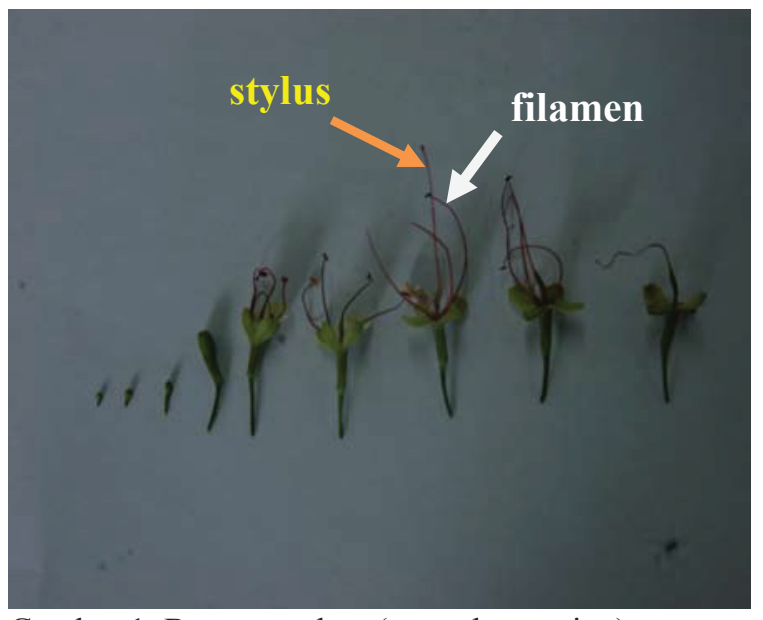

Gambar 1. Bunga merbau (tampak samping)

Pembungaan merbau di plot konservasi ex situ di Gunung Kidul dan Bondowoso lebih cepat dibandingkan Carita. Merbau yang ditanam di kebun percobaan litbang Carita berbunga pada umur $10 \mathrm{t}$ ahun. Bunga merbau berupa bunga majemuk dalam bentuk malai, tangkai utama 5-18 cm dan panjang tajuk bunga 1,5-2,5 $\mathrm{cm}$. Buah merbau berbentuk polong, bulat, atau berbentuk agak panjang. Benih merbau berbentuk bulat pipih dan berwarna coklat tua kemerah-merahan. Bunga mekar pada bulan November sampai Januari dan buah tua pada bulan Mei sampai Agustus Buah siap dipanen setelah masak fisiologis dengan ciri-ciri warna buah coklat tua (correlation of paternity) yang rendah yaitu 0,269 (Kerom) dan 0,147 (Manokwari) mengindikasikan rendahnya probabilitas full sib pada keturunan yang berasal dari satu pohon ( Ningsih, 2008). Tanaman merbau pada kedua plot konservasi berbunga pertama kali pada umur 4 tahun.

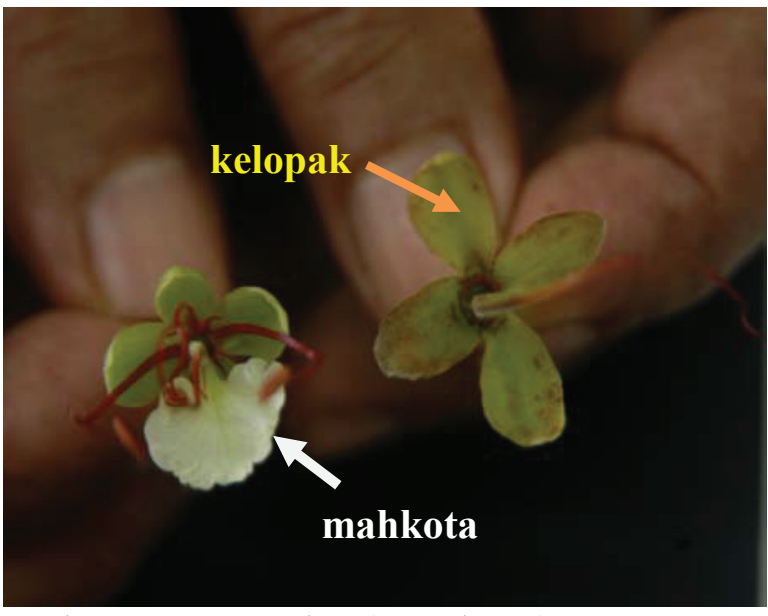

Gambar 2. Bunga merbau (tampak atas)

sampai kehitam-hitaman, kulit buah keras dan benih berwarna coklat tua kemerahan (Yuniarti, 1994 dan 2000).

Proses pembungaan merbau pada plot konservasi ex situ di Gunung Kidul dan Bondowoso dimulai pada musim penghujan. Pada plot konservasi ex situ di Gunung Kidul, kuncup bunga muncul dan mekar selama musim penghujan (November sampai pertengahan April) akan membusuk, rontok dan tidak dapat berkembang menjadi polong. Bunga yang mekar pada saat dimulainya musim kemarau (akhir April atau Mei) akan dapat berkembang menjadi polong buah. Polong buah merbau akan masak atau tua pada 
bulan Agustus dan pecah (over ripe) pada pertengahan bulan September. Pada plot konservasi ex situ di Gunung Kidul proses pembungaan berlangsung sempurna dan mampu menghasilkan biji. Polong buah merbau yang sudah masak atau tua berwarna coklat tua hingga hitam (Gambar 3). Biji merbau yang sudah tua berwarna hitam dengan bentuk bulat pipih atau

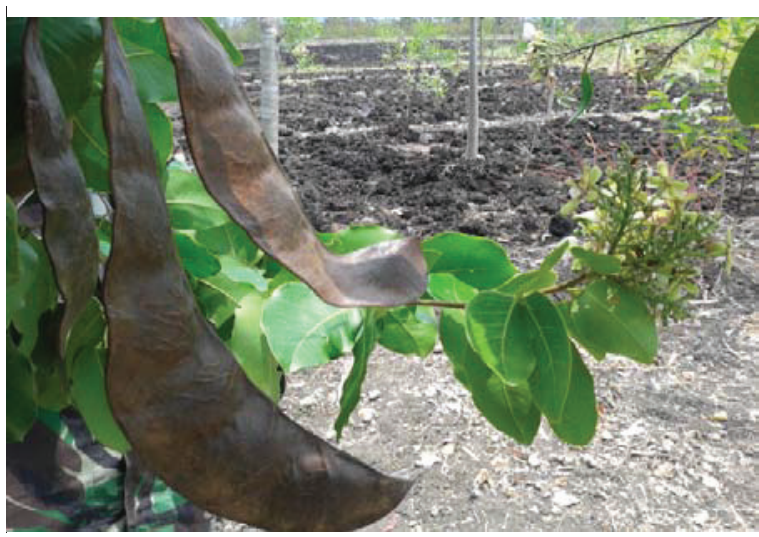

Gambar 3. Bunga dan polong buah masak konservasi ex situ merbau di Gunung Kidul

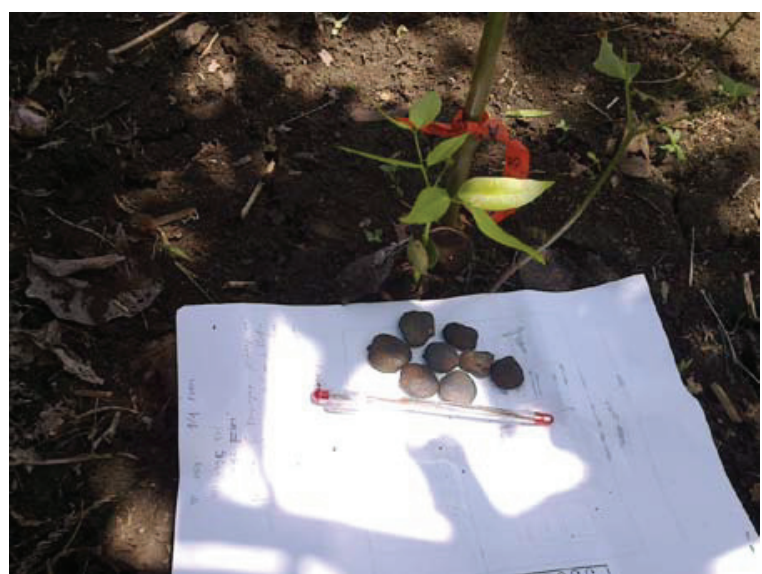

Gambar 5. Biji dan anakan merbau pada plot konservasi ex situ di Gunung Kidul

Pada plot konservasi ex situ di Bondowoso, kuncup bunga yang muncul dan mekar akan membusuk, rontok dan persegi panjang (Gambar 6). Polong buah yang lewat masak (over ripe) selanjutnya akan pecah (Gambar 4) dan biji akan jatuh. Penyebaran biji merbau tidak jauh dari pohon induknya karena biji merbau cukup berat. Bahkan biji merbau yang jatuh sudah mampu berkembang menjadi anakan alam (Gambar 5).

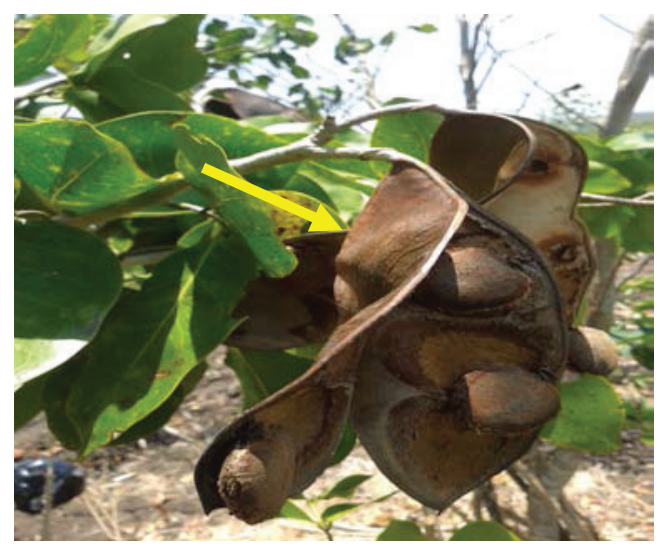

Gambar 4. Polong buah merbau over ripe Pada plot pada konservasi ex situ di Gunung Kidul

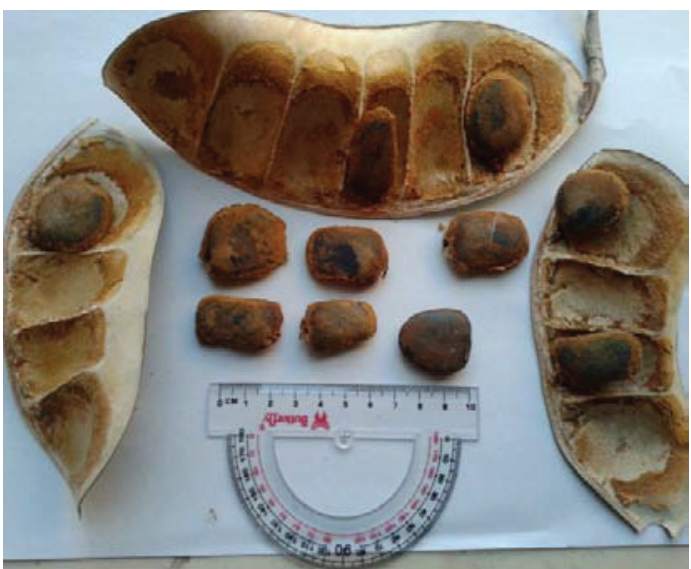

Gambar 6. Bentuk, warna dan ukuran biji merbau

tidak dapat berkembang menjadi polong buah baik selama musim penghujan maupun kemarau (Gambar 7 dan 8). 


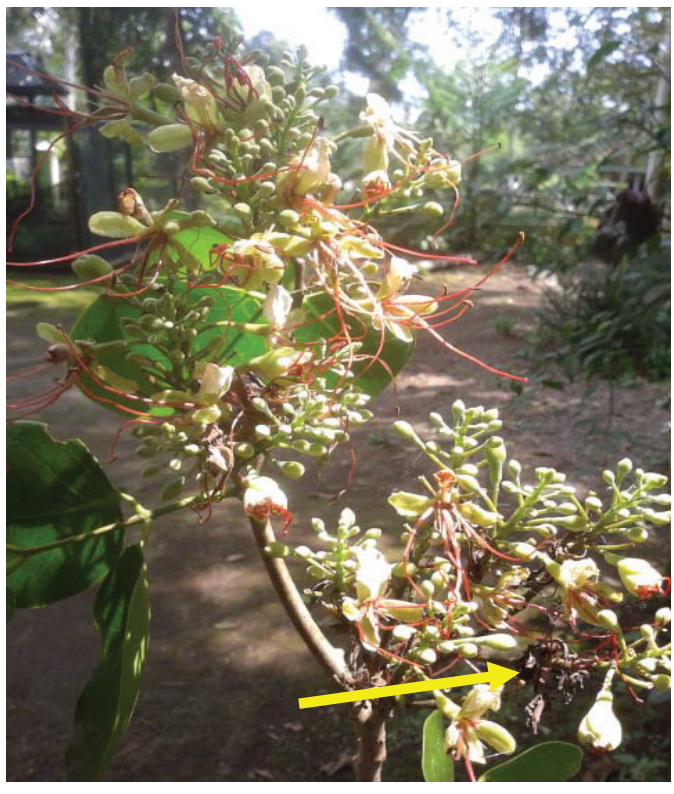

Gambar 7. Anthesis merbau membusuk dan rontok pada plot konser-vasi ex situ di Bondowoso

Proses pembungaan merbau belum berlangsung sempurna dan belum mampu menghasilkan biji pada plot konservasi ex situ di Bondowoso. Tahapan pembungaan yang sudah dilalui tanaman merbau pada plot konservasi ex situ di Bondowoso baru sampai pada tahap anthesis. Kondisi ini diduga dipengaruhi oleh faktor iklim dan kondisi tanah pada kedua plot konservasi ex situ. Curah hujan merupakan salah satu faktor iklim yang mempengaruhi pembungaan. Curah hujan pada plot konservasi ex situ di Bondowoso lebih tinggi dibandingkan plot konservasi ex situ di Gunung Kidul. Plot konservasi ex situ di Bondowoso memiliki tipe iklim B dengan curah hujan $2400 \mathrm{~m} \mathrm{~m} / \mathrm{th}$ dan plot konservasi ex situ di Gunung Kidul memiliki tipe iklim $\mathrm{C}$ dengan curah hujan $1800 \mathrm{~mm} / \mathrm{th}$. Disamping itu, lebah yang

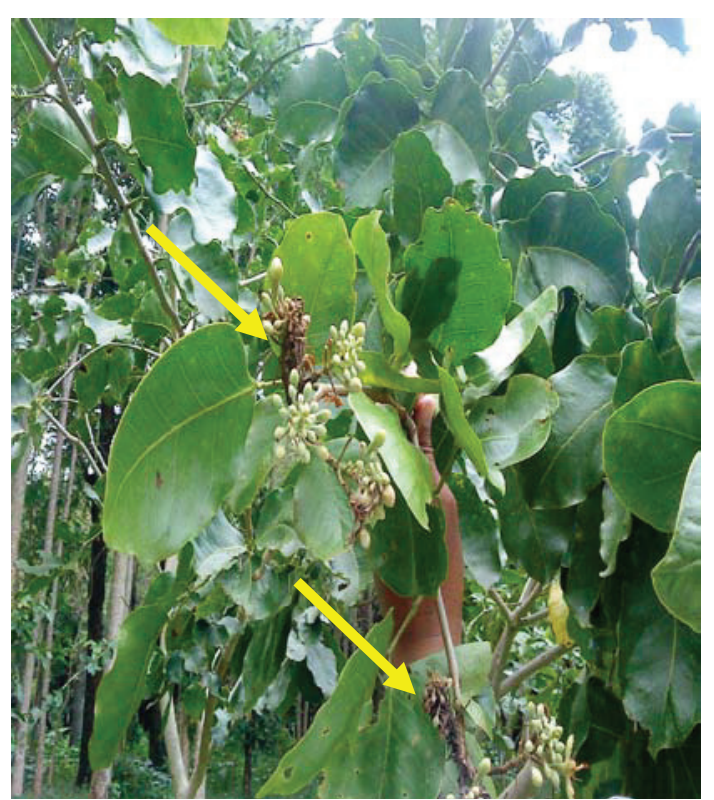

Gambar 8. Kuncup bunga merbau mekar membusuk dan rontok pada plot konservasi ex situ di Bondowoso

merupakan agen penyerbuk juga tidak banyak dijumpai pada konservasi ex situ di Bondowoso yang mempunyai kondisi cuaca yang sangat basah.

Selain faktor iklim dalam hal ini curah hujan, kondisi tanah pada kedua plot konservasi juga diduga mempengaruhi keberhasilan proses pembungaan merbau. Sebagian besar tanah pada plot konservasi ex situ di Gunung Kidul adalah berbatu dengan solum tanah yang dangkal (kurang dari $30 \mathrm{~cm}$ ). Ketersediaan air dalam tanah menjadi faktor pembatas pertumbuhan tanaman merbau di Gunung Kidul. Sedangkan pada plot konservasi ex situ di Bondowoso solum tanahnya cukup dalam (lebih dari $50 \mathrm{~cm}$ ) dan tersedia cukup banyak air. Keterbatasan air di Gunung Kidul membuat tanaman sering mengalami cekaman (stress) air. Meskipun cekaman air 
dapat menghambat pertumbuhan tanaman merbau tetapi di sisi lain cekaman air ini bisa berdampak positif untuk memacu inisiasi bunga tanaman merbau. Pembungaan di daerah tropis merupakan respon terhadap turunnya ketersediaan air dalam tanah. Menurut Mugnisjah dan Setiawan (1995), cekaman air yang diikuti oleh hujan sering merangsang pembungaan tanaman tahunan tropika.

\section{Adaptabilitas}

Finkeldey dan Hans (2007), menyatakan bahwa umur dan imobilitas tumbuhan mengimplikasikan bahwa mereka perlu bertahan terhadap kondisi lingkungan yang berbeda selama hidupnya. Adaptasi tumbuhan terhadap lingkungannya merupakan persyaratan/kebutuhan untuk dapat bertahan hidup. Keberadaptasian mencerminkan tingginya kemampuan bertahan hidup dan reproduksi pada suatu lingkungan tertentu. Berdasarkan parameter yang diamati (persen hidup, pertumbuhan tanaman dan kemampuan berbunga/ regenerasi) pada kedua plot konservasi ex situ, merbau dapat beradaptasi dengan cukup baik pada kedua plot konservasi tersebut. Secara umum, berdasarkan dari besaran nilai parameter tersebut maka kemampuan beradaptasi tanaman merbau pada plot konservasi ex situ di Gunung Kidul lebih baik dibandingkan Bondowoso.

\section{KESIMPULAN}

1. Tanaman merbau dari tujuh provenan yang diuji mempunyai kemampuan beradaptasi dengan cukup baik pada plot konservasi ex situ di Petak 93, Gunung Kidul dan HP Sumberwringin, Bondowoso. Kesesuaian persyaratan tumbuh antara habitat alam merbau dengan kondisi lingkungan pada kedua plot konservasi ex situ merbau tersebut dan tingginya keragaman genetik merbau telah memberikan peranan yang besar terhadap kemampuan beradaptasi tersebut.

2. Perbedaan provenan dan karakteristik tempat tumbuh pada kedua plot konservasi ex situ merbau juga memberikan pengaruh terhadap pertumbuhan dan regenerasi merbau. Adanya variasi pertumbuhan tinggi dan diameter diantara provenan yang diuji provenan mengindikasikan bahwa provenan memberikan pengaruh terhadap karakterisitik tinggi dan diameter tanaman merbau. Pertumbuhan tinggi dan diameter tanaman merbau pada plot konservasi ex situ Petak 93, G unung Kidul lebih baik dibandingkan HP Sumberwringin, Bondowoso pada semua umur pengamatan. Regenerasi merbau sudah berlangsung dengan baik dan berhasil pada plot konservasi ex situ Petak 93, G unung Kidul. Sedangkan 
pada plot konservasi ex situ HP

Sumberwringin, Bondowoso, regenerasi

merbau belum berhasil atau tidak

berlangsung dengan baik

\section{UCAPAN TERIMA KASIH}

Penulis mengucapkan terima kasih kepada semua pihak yang membantu kelancaran penelitian ini, khususnya kepada Bapak Diro Eko Pramono, S.Hut.T dan yang telah membantu dalam kegiatan pengukuran dan entry data .

\section{DAFTAR PUSTAKA}

Finkeldey, R and Hattemer, H.H. 2007. Tropical Forest Genetics. Springer-Verlag Berlin Heidelberg.

Finkeldey, R. 2005. An introduction to tropical forest genetics. Institute of Forest Genetics and Forest Tree Breeding, Georg-August-University Göttingen, Büsgenweg 2, D -37077 Göttingen, Germany.

Ginwal, H.S and A.K. Mandal. 2004. Variation in Growth Performance of Acacia nelotica Willd. Ex Del. Provenances of Wild Geographical Origin : Six Years Results. Silvae Genetica 53 Issue 5-6 : 264-269

Hamrick, J.L., Godt, M.J.W., Murawki, D.A. and Loveless, M.D. 1991. Correlation between species traits and allozyme diversity : implications for conservation biology. In A.D. Falk and K.E. Holsinger (eds). Genetics and conservation of rare plants, 75-83. Oxford University Press, New York, USA.

IUCN. 1994. I UCN Red List Categories. Prepared by the IUCN Species Survival Commission. IUCN, Gland, Switzerland.

Lee, S.L., Kevin, K.S., Leng-Guan S., Adnan N., Siti S., Chai-Ting L., and Muhammad N. 2002. Population genetics of Intsia palembanica (Leguminosae) and genetic conservation of virgin jungle reserve in Peninsular Malaysia. American Journal of Botany 89 (3): 447-459.

Loveless, M.D. and J.L. Hamrick. 1984. Ecological Determinant Genetic Structure in Plant Population. Ann.Rev.Ecol.Syst. $15: 65-95$

Mahfudz, Sugeng, P., T.Pamungkas, Pudja, M.U dan Batseba A.S.. 2006. Merbau (Intsia spp) dan Upaya Konservasinya. Puslitbang Hutan Tanaman. Badan Litbang Kehutanan. Yogyakarta.

Mahfudz, T.P. Yudohartono, dan Sugeng, P. 2006. Pembangunan Kebun Konservasi Jenis Merbau (Intsia spp). Laporan Akhir. Puslitbang Bioteknologi dan Pemuliaan tanaman Hutan. Yogyakarta.

Mugnisjah, W. Q., dan A. Setiawan. 1995. Produksi benih. Penerbit Bumi Aksara.

Na'iem, M. 2004. Uji genetik sebagai elemen dasar kegiatan pemuliaan pohon dalam Dari Bukit-bukit Gundul sampai ke Wanagama I. Yayasan Sarana Wanajaya, Jakarta.

Nei, M. 1972. Genetic distance between populations. American Naturalist, 106, 283-92

Ningsih, A.N. 2008. Sistem perkawinan pada sebaran alam merbau (Intsia bijuga (Colebr) O. Kuntze) di Papua berdasarkan analisis isozim. Skripsi Jurusan Budidaya Hutan, Fakultas Kehutanan, Universitas Gadjah Mada, Yogyakarta.

PPPBPTH (Pusat Penelitian dan Pengembangan Bioteknologi dan Pemuliaan Tanaman Hutan). 2004a. Sekilas Tentang Hutan Penelitian Sumberwringin Bondowoso. Yogyakarta.

PPPBPTH (Pusat Penelitian dan Pengembangan Bioteknologi dan Pemuliaan Tanaman Hutan). 2004b. Sekilas Tentang Hutan Penelitian Petak 93 Gunung Kidul. Yogyakarta.

Soetrisno, K. 1998. Silvikultur. Fakultas Kehutanan, Universitas Mulawarman, Samarinda

Thaman, R.R., Lex, A.J., Robin, D., Francis A., and Craig, R.E. 2006. Intsia bijuga (vesi). Species Profiles for Pacific Island Agroforestry. www.traditionaltree.org

Thomas. 1993. Internal and External Control of Flowering. In: Jordan BR (Ed) Moleculer Biology of Flowering. Sussex. CAB International 
Whitmore, T.C (ed). 1987. Biogeographical evolution of the Malay Archipelago. Oxford Forestry Institute, University of Oxford. CLARENDON PRESSOXFORD

Yudohartono, T.P. 2008. Studi Variasi Genetik Beberapa Populasi Merbau (Intsia Bijuga O.Ktze) Menggunakan Penanda Isoenzim dan Pemanfaatannya dalam Program Konservasi Genetik. Tesis Program Studi Ilmu Kehutanan Jurusan, Fakultas Kehutanan, Universitas Gadjah Mada, Yogyakarta.

Yudohartono, T.P. dan Burhan, I. 2012. Variasi Genetik Uji Provenan Merbau Sampai Umur Tiga Tahun di Bondowoso, Jawa Timur. Jurnal Penelitian Hutan Tanaman Vol.6 No.1, Juli 2012. Balai Besar Penelitian Bioteknologi dan Pemuliaan Tanaman Hutan. Badan Penelitian dan Pengembangan Kehutanan, Departemen Kehutanan.
Yuniarti, N. 2000. Merbau (Intsia spp). Atlas benih tanaman hutan Indonesia. Publikasi Khusus Vol. 2 N o. 3. Balai Teknologi Perbenihan. Badan Litbang Kehutanan dan Perkebunan. Bogor.

Yuniarti, N. 1994. Teknik Budidaya Merbau (Intsia spp) untuk Pembangunan Hutan Tanaman. Klon. Informasi dan Komunikasi Benih Vol $2 \mathrm{~N}$ o.01. Balai Penelitian dan Pengembangan Teknologi Perbenihan. Badan Litbang Kehutanan dan Perkebunan. Bogor.

Zobel, B., Mc.Kee, A., Hoek, G.M., and Dyrness, C. 1976. R elationship of environment to composition, structure and diversity of forest communities of the central western carcades of $\mathrm{O}$ regon. Ecol.Mono. 46: 135-156.

Zobel, B ., and Talbert, J. 1984. Applied forest Tree Improvement. Waveland Press Inc. John Wiley \&Son, Inc, New York. 
Jurnal Pemuliaan Tanaman Hutan

Vol 7 No. 3, November 2013, 179 - 196 